\title{
Kewajiban Negara Untuk Menerima Bantuan Kemanusiaan Dalam Hal Terjadinya Internal Displaced Persons Dalam Perspektif Hukum Internasional
}

\author{
Sri Wartini
}

\begin{abstract}
Abstrak
A State as one of International law subjects has rights and obligations based on international law. One of the international obligations of a State is to assist and protect the right of IDP's in its territory. If a State is inability and unwillingness to assist and protect the IDP's rights, it means the State has already violated its international obligation. In this condition, is the humanity assistance of international organization can be justified as an obligation that must be accepted based on international law perspective?. Consequently, the refusal to accept assistance can be classified as a violation of international law, and it raises state responsibility.
\end{abstract}

\section{Pendahuluan}

Dahsyatnya akibat badai tsunami yang dialami masyarakat di Aceh mengundang perhatian dan simpati seluruh kekuatan negeri ini bersama-sama memulihkan kehidupan bumi serambi Mekkah. Banyak anak-anak yang kehilangan orang tuanya maupun orang tua yang kehilangan anak-anaknya dan pengungsi yang bingung mencari bantuan. Badai tsunami yang membawa gelombang air bah maha dahsyat berkecepatan $800 \mathrm{~km}$ per jam, menggulung apa saja yang tergelar di bumi Aceh. Di daerah bencana tersebut kini tiada lagi makna kekuasaan, tidak berarti lagi kemewahan, ketika batas hidup dan kematian begitu tipis, saat kematian merenggut cepat kehidupan. ${ }^{1}$
Warga yang berhasil selamat dari bencana tersebut, telah disiapkan beberapa tempat pengungsian untuk korban bencana alam ini. Berbagai bantuan baik itu berupa bahan makanan, obat-obatan maupun pakaian mengalir begitu banyak, hanya saja distribusinya yang belum dapat dilakukan sebagaimana mestinya, sehingga masih banyak pengungsi yang belum menerima bantuan. Solidaritas internasionalpun muncul begitu terjadi bencana besar di Aceh. Mulai Kamis 6 Januari 2005, negara-negara ASEAN menggelar Konferensi Tingkat Tinggi Luar Biasa untuk membahas sejumlah agenda penting berkaitan dengan bencana ini.

Di tempat pengungsian tersebut, banyak anak-anak yang kehilangan orang tuanya,

\footnotetext{
'Abdul Munir Mulkan, "Fatwa Jihad bagi Pemulihan Korban Tsunami," Republika, 5 Januari 2005.
} 
menggugah banyak orang untuk melakukan pengadopsian terhadap anak-anak malang tersebut, namun banyak juga orang yang memancing di air keruh dengan berkedok adopsi, mereka berusaha untuk menjual anak-anak tersebut tidak ubahnya seperti barang dagangan saja. Penanganan anakanak Aceh korban gempa dan stunami makin penting. Pemerintah punya tanggung jawab terhadap anak-anak Aceh untuk melindungi hak-hak mereka, sebagaimana anak-anak yang lain. Anak-anak merupakan penerus generasi, jangan sampai hak-hak mereka terampas akibat bencana ini. Pengungsi yang disebabkan oleh bencana alam sebagaimana yang terjadi di Aceh ini, menurut ketentuan hukum intemasional disebut Intemal Displaced Persons (IDPs), selanjutnya akan disebut IDPs. ${ }^{2}$

Sebagian besar pengungsi domestik yang ada di dunia adalah pengungsi domestik yang timbul akibat adanya konflik bersenjata, baik konflik bersenjata internasional maupun noninternasional seperti yang terjadi di Indonesia. Beberapa sengketa bersenjata non-internasional yang tejadi di berbagai negara tersebut mulai awal tahun 1990 hingga sekarang masih menimbulkan berbagai masalah terutama mengenai perlindungan bagi pengungsi domestik akibat konflik bersenjata noninternasional. Di Indonesia telah terjadi pengungsi domestik yang berasal dari beberapa wilayah di Indonesia yang disebabkan oleh konflik bersenjata internal seperti di Ambon dan Maluku Utara, Sambas dan di Aceh, ${ }^{3}$ orang Aceh menjadi pengungsi domestik akibat konflik bersenjata antara pemerintah Indonesia dengan tentara Gerakan Aceh Merdeka (GAM). Pengungsi Aceh yang semula hanya disebabkan oleh konflik bersenjata sekarang bertambah dengan pengungsi yang disebabkan oleh bencana alam. Beban pemerintah Indonesia semakin berat untuk memberikan perlindungan dan bantuan kepada para pengungsi ini.

Masalah yang dihadapi IDPs akibat konflik non-internasional maupun akibat bencana alam adalah masih minimnya perlindungan atas hak-haknya, diantaranya keadaan pengungsi yang kacau balau, terpisahnya anggota keluarga yang satu dengan yang lain, kurangnya makanan, sarana air bersih, serta sarana sanitasi yang kurang layak, juga terjadinya wabah penyakit dan tekanan batin yang mereka alami mengakibatkan meningkatnya angka kematian para pengungsi.

Berdasarkan perspektif hukum internasional, negara bertanggung jawab untuk melindungi dan memberikan bantuan kepada pengungsi domestik (IDPs), karena ini didasarkan pada prinsip kedaulatan negara dan prinsip nonintervensi. ${ }^{4}$ Bagi negara-negara maju, mereka

${ }^{2}$ Istilah IDPs (pengungsi domestik) ini pertama kali muncul pada saat terjadinya konflik senjata internal di Sudan pada tahun 1972, dimana konflik internal tersebut mengakibatkan banyak rakyat Sudan harus meninggalkan kampung halamannya untuk mencari tempat yang lebih aman tetapi masih di wilayah Sudan. Pada tahun 1990-an dan periode berakhimya perang dingin banyak terjadi konflik internal di negara-negara di dunia yang mengakibatkan sejumlah orang di Afrika, Asia, Eropa dan Amerika Latin terpaksa meninggalkan tempat tinggalnya sebagai akibat konflik bersenjata, kerusuhan internal, dan pelanggaran hak asasi manusia. Lihat Achmad Romsan. et. al., Pengantar Pengungsi internasional (Jakarta: UNHCR, 2003), hlm. 32.

${ }^{3}$ Dahlan, "Pengungsi Domestik di Aceh (Peta Permasalahan dan Alternatif Penyelesaian secara Simultan) Makalah disampaikan di Hotel Bumikarsa Jakarta, 6- 7 Februari 2001 dalam, Achmat Romsan, et. al., op.cit., hlm. 195. 
akan berusaha untuk melindungi dan menyediakan bantuan bagi IDPs, akan tetapi karena terjadinya IDPs di suatu negara selain disebabkan oleh bencana alam, juga disebabkan oleh karena terjadinya konflik bersenjata internal, atau karena pelanggaran hak asasi manusia secara sistematis, maka kadang-kadang negara tidak berkehendak dan tidak mampu untuk memberikan bantuan maupun perlindungan, bahikan menolak bantuan kemanusiaan berasal dari organisasi internasional, seperti UNHCR atau Red-Cross demi mempertahankan kedaulatan negaranya.

Dengan adanya bencana yang menimpa masyarakat Aceh dan juga pengungsi yang disebabkan oleh konflik antar suku di Kalimantan Barat, konflik antar agama di Poso, yang menyebabkan terjadinya IDPs di Indonesia, membuat penulis tertarik untuk menganalisis sampai sejauh mana negara harus bertanggung jawab terhadap pengungsi domestik (IDPs) berdasarkan perspektif hukum internasional baik yang disebabkan oleh bencana alam atau bencana yang dibuat oleh manusia seperti adanya konflik internal. Adakah kewajiban negara untuk menerima bantuan kemanusiaan atas terjadinya IDPs tersebut? Perlukah persetujuan negara yang bersangkutan untuk menerima bantuan internasional?

\section{Pengertian Pengungsi Domestik (Internal Displaced Persons)}

Pengertian pengungsi domestik (IDPs) atau orang-orang yang terlantar digunakan oleh PBB dan United Nations High Commissioner Refugees (UNHCR) pertama kali pada tahun
1972. Sejak tahun 1975, UNHCR dan PBB memakai istilah displaced persons untuk menunjuk orang-orang yang meninggalkan kampung halamannya untuk pergi ke tempat lain yang dirasanya aman, sebagai akibat terjadinya konfllik bersenjata di negara asalnya, tetapi yang sudah berada di luar perbatasan negara asalnya. Untuk Displaced Persons dalam pengertian semula (tetap berada dalam wilayah negara yang sama), UNHCR memakai istilah Internally Displaced Persons (IDPs) untuk menyebut pengungsi domestik. ${ }^{5}$

Guiding Principles on Intemal Displacement memberikan perlindungan terhadap pengungsi domestik termasuk hak dan kewajiban para pengungsi beserta kewajiban negara yang bersangkutan untuk melindungi para pengungsi domestik tersebut. Selain itu juga ada jaminan hak bagi pengungsi domestik untuk meminta bantuan internasional, dan hak bagi masyarakat internasional untuk memberikan bantuan, serta kewajiban bagi pemerintah yang bersangkutan untuk menerima bantuan. Dalam angka 2 Guiding Principles on Internal Displacement tentang pengantar, memuat pengertian istilah Internally Displaced Persons atau pengungsi Domestik sebagai berikut:

"...internally displaced persons are persons or groups of persons who have been forced or obliged to flee or to leave their homes or places of habitual residence, in particular as a result of or in order to avoid the effects of armed conflict, situations of generalized violence, violations of human rights or natural or human made disasters, and who have not crossed an intemationally recognized State border".

${ }^{4}$ Geoff Gilbert, ed, Artikel dalam International Journal of Refugee Law, Vol. 15. No. 4 (Human Rights Center University of Essex, Oxford Universirty Press, 2000), hlm. 681.'

${ }^{5}$ Achmad Romsan, et. al., loc. cit. 
Berdasarkan definisi tersebut, istilah IDPs atau pengungsi domestik timbul karena adanya bahaya yang mengancam keselamatan penduduk. Seperti adanya pertikaian bersenjata, atau karena banyaknya terjadi pelanggaran hak asasi manusia atau karena terjadi bencana alam seperti banjir, gempa bumi, gunung meletus, kekeringan, atau karena bencana buatan manusia.

Pengungsi domestik, terdiri dari beberapa kategori menurut latar belakang terjadinya pengungsian tersebut, dan masing-masing jenis pengungsi domestik ini memiliki penanganan yang berbeda-beda. Beberapa kategori pengungsi tersebut ialah: Pertama, pengungsi yang disebabkan oleh peristiwa alami atau natural disaster seperti gunung meletus, gempa bumi, banjir, dan kekeringan. Bagi pengungsi akibat natural disaster ini penangannannya lebih sederhana, mengingat bahwa kebutuhan utama mereka adalah dapat tinggal untuk sementara di tempat menyelamatkan diri dan untuk dapat hidup dalam waktu singkat sampai tiba saatnya kembali ke kampung halamannya. Pertolongan yang diutamakan ialah makanan, air, pakaian, sanitasi, dan kesehatan.

Kedua, Pengungsi yang disebabkan oleh perbuatan manusia atau sering disebut human made disaster, seperti konflik bersenjata, penindasan atau gangguan terus-menerus yang dilakukan oleh penguasa atau sekelompok orang di suatu negara terhadap golongan orang tertentu di negara yang bersangkutan, misalnya karena, ras, warna kulit, etnis, agama, golongan sosial, atau opini politik orang-orang yang menjadi sasaran penindasan atau gangguan terus menerus tersebut. Bagi pengungsi akibat human made disaster ini terutama korban gangguan terus-menerus terhadap pribadi atau kebebasan fundamental mereka atau kekerasan terhadap jiwa dan fisik, penanganannya lebih sulit karena tidak hanya membutuhkan pertolongan dan bantuan bagi kelangsungan hidup, akan tetapi, mereka membutuhkan perlindungan dari ancaman human disarter yang memerlukan perlindungan hukum internasional. Oleh karena itu, pengungsi domestik akibat bencana alam di suatu negara dan juga pengungsi karena konflik etnis dan konflik agama seperti yang terjadi di Indonesia dapat dimasukkan sebagai pengungsi domestik, sehingga berhak untuk memperoleh perlindungan atas hak-hak dan keselamatannya selama masa pengungsian.

\section{Hak-Hak IDPs}

IDPs sebagaimana pengungsi yang melewati batas-batas negara, juga berhak untuk memperoleh perlindungan hak-haknya berdasarkan hukum nasional maupun hukum internasional. Hak-hak pengungsi dimuat dalam prinsip 1 angka 1 Guiding Principles on Internal Displaced Persons yang menyatakan:

1. Internally diplaced persons shall enjoy in full equality, the same rights and freedoms under international and domestic law as do other persons in their country. They shall not be discriminated against in the enjoyment of any rights and freedom on the ground that they are internally displaced.

2. These principles are without prejudice to

${ }^{6}$ Kate Jastram dan Marilyn Achiron, Refugee Protection: A Guide to Intemational Refugee Law (UNHCR, 2001), hIm. 26. 
individual criminal responsibility under intermational law, in particular relating to genocide, crimes against humanity and war crimes. ${ }^{7}$

Berdasarkan prinsip tersebut ditegaskan bahwa pengungsi domestik (Internal Displaced Persons) akan menikmati, dengan persamaan penuh, hak dan kebebasan yang sama menurut hukum internasional dan hukum nasional sebagaimana orang-orang di negaranya. Mereka tidak boleh dibedakan dengan alasan bahwa mereka pengungsi domestik. Akan tetapi tidak meniadakan pertanggungjawaban kriminal menurut hukum internasional, terutama berkenaan dengan ketentuan genocida, kejahatan perang dan kemanusiaan.

Dengan demikian pemerintah suatu negara mempunyai tugas dan kewajiban untuk memberikan perlindungan dan bantuan kemanusiaan kepada orang-orang yang dipindahkan secara internal dalam wilayah teritorial suatu negara. Orang-orang yang dipindahkan secara internal memiliki hak untuk meminta dan menerima perlindungan serta bantuan kemanusiaan dari pemerintah mereka. Setiap pengungsi domestik menikmati hak yang sama, tanpa diskriminasi dalam bentuk apapun. Hal ini dipertegas dalam prinsip 4 angka 1 yang menyatakan "... shall be applied without discrimination of any kind, such as race, colour, sex, language, religion or belief, political, or other opinion, national, ethnic or social origin, legal or social status, age, disability, property, birth, or any other similar criteria ". 8
Perlindungan terhadap pengungsi domestik meliputi perlindungan terhadap hakhaknya sebagai pengungsi domestik antara lain:

Pertama, hak yang melekat untuk hidup yang terdapat dalam prinsip 10 angka1 sebagai berikut:

"Every human being has the inherent right to life which shall be protected by law. No one shall be arbitrarily deprived of his or her life. Internally displaced persons shall be protected in particular against:
a. Genocida;

b. Murder;

c. Summary or arbitrary executions; and Enforced disappearances, including abduction or unacknowledge detention, treatening or resulting in death. Threats and incitement to commit any of the foregoing acts shall be prohibited."

Berdasarkan ketentuan pasal tersebut, pengungsi domestik tidak dibedakan apakah karena bencana alam atau karena human disturbance dilindungi dari kejahatan genocida, pembunuhan, hukuman mati yang djjatuhkan dengan sewenang-wenang atau tanpa landasan hukum, dan penghilangan paksa yang mengakibatkan kematian. Yang dilarang tidak hanya tindakan-tindakan aktual yang merampas hak hidup para pengungsi domestik tersebut, tetapi juga ancaman-ancaman dan hasutan-hasutan untuk melakukan tindakan-tindakan seperti itu. ${ }^{10}$

Kedua, hak dan martabat dan integritas diri, pengungsi domestik akan dilindungi dari perbudakan, termasuk penjualan orang,

\footnotetext{
${ }^{7}$ Prinsip 1 Guiding Principles on Internal Displacement.

${ }^{8}$ Pasal 4 ayat (1) Guiding Principles on Internal Displaced Person.

${ }^{9}$ Pasal 10 angka 1 Guiding Principles on Internal Displaced Person.
} 
eksploitasi seksual, dan kerja paksa anakanak. Ancaman-acaman serta hasutanhasutan untuk itu juga dilarang. Mereka juga mendapatkan perlindungan dari penangkapan dan perlindungan sewenang-wenang. Dalam hal ini, berarti pemerintah tidak boleh menagkap atau menahan orang dengan sewenang-wenang, seperti menangkap dan menahan pengungsi domestik hanya karena dia telah mengungsi atau karena alasan-alasan lain, seperti tidak mempunyai dokumen dan surat menyurat yang dibutuhkan, kebebasan bergerak dan kebebasan kemerdekaan dan keamanan diri."1

Ketiga, berhak untuk memilih sendiri tempat tinggainya, dilindungi dari pemulangan paksa, dilindungi dari perekrutan militer secara paksa, ${ }^{12}$ hak untuk mengetahui keadaan keluarga pengungsi yang hilang dan hak untuk memperoleh standar hidup yang memadai, hak atas perlindungan terhadap harta kekayaannnya, hak atas pendidikan.

\section{Kewajiban Negara terhadap IDPs}

Negara sebagai salah satu subjek hukum internasional mampu untuk mengemban kewajiban internasional dan memiliki hak-hak berdasarkan hukum internasional. Salah satu kewajiban utama suatu negara adalah untuk memberlakukan semua orang yang berada di wilayahnya secara baik dengan memberikan perlindungan terhadap hak-hak asasi manusia. ${ }^{13}$ Dalam hal terjadinya IDPs di wilayah suatu negara, mengakibatkan negara berkewajiban untuk melindungi hak asasi IDPs ini, karena IDPs merupakan warga negara sendiri, sehingga berdasarkan hukum internasional negara memiliki kewajiban untuk melindungi semua orang yang berada di wilayah negaranya. Apalagi IDPs juga merupakan warga negara dari negara yang bersangkutan. Jadi sudah seharusnya kalau negara memiliki kewajiban untuk melindungi hak asasi para IDPs ini.

Kewajiban pemerintah negara tempat: terjadinya IDPs diatur dalam Pasal 3 Guiding Principles on Internal Displacement yang menyatakan: "National authorities have the primary duty and responsibilities to provide protection and humanitarian assistance to internally displaced persons within their jurisdiction". ${ }^{14}$ Berdasarkan ketentuan pasal ini, jelas disebutkan bahwa pemerintah memiliki kewajiban untuk memberikan perlindungan dan bantuan kemanusiaan kepada pengungsi domestik dalam batas yurisdiksi mereka.

Bagian II Guiding Principles on Internal Displacement (prinsip 5 - 9) menyebutkan bahwa semua pejabat dan pelaku internasional harus menghormati dan menjamin penghormatan terhadap kewajiban mereka menurut hukum internasional, termasuk hukum humaniter dan hukum hak asasi manusia, dalam keadaan apapun, untuk mencegah dan menghindari keadaan-keadaan yang dapat merugikan orangorang yang dipindahkan. ${ }^{15}$

${ }^{10}$ Susan Forbes Martin, Pegangan untuk Penerapan Prinsip-Prinsip Panduan bagi Pengungsian Internal, (Jakarta: UN-OCHA, 2002), hlm. 29.

${ }^{11} \mathrm{lbid}$.

${ }^{12}$ Prinsip 13 Gujding Principles on Internal Displacement.

${ }^{13}$ Huala Adolf, Aspek-Aspek Negara dalam Hukum Internasional (Jakarta: Rajawali Press, 1991), hlm. 39.

${ }^{14}$ Prinsip 3 Guiding Principles on Internal Displacement. 
Prinsip 7 mengatur kewajiban negara untuk menjamin penampungan yang memadai dengan kondisi yang memuaskan atau layak tentang keselamatannya, gizi, kesehatan dan kebersihan, selain itu anggota keluarga yang sama tidak boleh dipisahkan. Secara jelas disebułkan dalam prinsip 7 angka 2 sebagai berikut:

"the authorities undertaking such displacement shall ensure, to the greatest practicable extent, that proper accomodation is provided to the displaced persons, that such displacement are effected in satisfactory conditions of safety, nutrition, health and hygiene, and that members of the same family are not separated". ${ }^{16}$

Prinsip 25 mengatur bahwa pihak-pihak yang berwenang di tingkat nasional memiliki tanggung jawab dan kewajiban yang paling utama terhadap pengungsi domestik (ayat (1)). Organisasi-organisasi internasional dan pelaku-pelaku lain di bidang kemanusiaan memiliki hak untuk menawarkan jasa-jasa mereka dalam upaya membantu pengungsi domestik, dan pihak berwenang tidak boleh menunda persetujuan tawaran bantuan tersebut dengan sewenang-wenang (ayat (2)). Pihak berwenang juga harus mengijinkan orang-orang yang terlibat dalam penyediaan bantuan semacam itu akses yang cepat dan tanpa hambatan kepada para pengungsi. ${ }^{17}$

\section{Aspek Hak Asasi Manusia dalam IDPs}

Pengungsi domestik (IDPs) merupakan segolongan manusia yang sangat rentan terhạdap perlakuan sewenang-wenang oleh para penguasa maupun oleh masyarakat di tempat mereka mengungsi. Sebagai individu, kelompok masyarakat dan sebagai manusia, mereka berhak mendapat perlakuan yang manusiawi. Setiap pengungsi berhak mendapatkan perlindungan baik oleh hukum nasional maupun hukum internasional, sekalipun instrumen hukum internasional yang mengatur mengenai perlindungan IDPs bukanlah merupakan ketentuan hukum yang mengikat, karena hanya berupa pedoman saja. Akan tetapi, IDPs sebagai manusia juga berhak memperoleh perlindungan berdasarkan instrumen hukum hak asasi manusia. ${ }^{18}$

Secara garis besar hak-hak yang melekat kepada diri seorang IDPs adalah hak-hak yang menyangkut hak-hak sipil, politik, ekonomi, sosial dan budaya, yang berlaku untuk semua orang baik warga negara maupun bukan warga negara. Semua hak-hak tersebut dituangkan dalam the Intemational Bill of Human Rights yang terdin dari the Universal Declaration of Human Rights, the Intemational covenant on Civil and political Rights, dan the International Covenant on Economic, Social, and Cultural Rights. ${ }^{19}$ Beberapa Konvensi Internasional lain dalam bidang Hak Asasi Manusia yang berkaitan dengan IDPs juga memberikan perlindungan kepada pengungsi adalah:

\footnotetext{
${ }^{15}$ Prinsip 5-9 Guiding Principles on Internal Displacement.

${ }^{16}$ Prinsip 7 angka 2 Guiding Principles on internal Displaced Persons.

${ }^{17}$ Prinsip 25 ayat (1) - (2) Guiding Principles on internal Displaced Persons.

${ }^{18}$ Pasal 2 Declaration of Human Rights.

${ }^{19}$ Martin Dixon. MA, International Law (London: Blackstone Press Limited, Third Edition, 1996), hlm. 313-314.
} 


\section{Konvensi Internasional tentang}

Penghapusan Segala Bentuk

Diskriminasi Rasial (United Nations

Convention on Elimination of Racial Discrimination)

Dalam Konvensi ini istilah "diskriminasj ras" diartikan sebagai segala bentuk pembedaan, pengecualian, pembatasan, atau pengutamaan berdasarkan ras, warna kulit, keturunan atau kebangsaan atau suku bangsa, yang mempunyai maksud atau dampak meniadakan atau merusak pengakuan, pencapaian atau pelaksanaan, atas dasar persamaan, hak asasi manusia dan kebebasan dasar dalam bidang politik, ekonomi, sosial budaya atau bidang kehidupan masyarakat lainnya. ${ }^{20}$ Perlindungan terhadap IDPs dalam Konvensi ini berkaitan dengan hak sipil dan hak ekonomi.

Konvensi ini selain mengatur hak-hak tersebut di atas juga mengatur tentang hak atas keamanan dan perlindungan pribadi sebagaimana yang dituangkan dalam Pasal $5 b$ Konvensi Intemasional tentang Penghapusan Segala Bentuk Diskriminasi Rasial sebagai berikut:

"The right to security of person and protection by the state against violence or bodily harm, whether inflicted by government officials or by any individual, group or institution."

Dengan demikian, setiap orang (termasuk IDPs) tanpa diskriminasi menikmati hak keamanan dan perlindungan pribadi dari negara terhadap pelanggaran yang membahayakan tubuh, baik yang disebabkan oleh pejabat pemerintah atau individu, kelompok atau lembaga.
Konvensi ini juga mewajibkan negara peserta untuk menjamin setiap orang di dalam wilayahnya memperoleh perlindungan dan upaya penyelesaian yang efektif terhadap tindakan diskriminasi ras yang melanggar hak asasi manusia dan kebebasan dasar maupun hak untuk memperoleh perbaikan dan penggantian yang adil dan layak. ${ }^{21}$

\section{Konvensi Anti Penyiksaan}

Konvensi ini secara lengkap berjudul "The Convention Against torture and Other Inhuman or Degrading Treatment or punishment 1984." Elemen inti dari perlindungan internasional dalam Konvensi tentang Anti Penyiksaan adalah hak untuk tidak dipulangkan secara paksa ke tempat yang dapat mengancam jiwa atau kemerdekaan seseorang. Pasal 3 Konvensi Anti Penyiksaan menyatakan:

1. No State Pairty shall expel, return (refouler) or extradite a person to another State wherethere are substancial grounds for believing that they would be in danger of being subjected to torture.

2. For the purpose to determining whether there are such grounds, the competent authorities shall take into account all relevant considerations including, where applicable, the existance in the State concemed of a consistent pattem of gross, flagrant or mass violations of human rights.

\section{Konvensi mengenai Penghapusan}

Segala Bentuk Diskriminasi terhadap Wanita (Convention on the Elimination of all Forms of Discrimination Against Women) 1979

\footnotetext{
${ }^{20}$ Pasal 1 Konvensi Internasional tentang Penghapusan Segala Bentuk Diskriminasi Rasial.

${ }^{21}$ Pasal 6 Konvensi Internasional tentang Penghapusan Segala Bentuk Diskriminasi Rasial.
} 
Konvensi ini dalam pembukaannya menyebutkan "...that the State Parties in the international Covenants on Human Rights have the obligation to ensure the equal rights of men and women to enjoy all economic, social, cultural, civil and political rights." Jadi ada persamaan derajat antara laki-laki dan wanita dalam menikmati hak ekonomi, sosial, budaya, sipil dan politik. Kemudian yang dimaksud dengan istilah diskriminasi terhadap wanita adalah:

"...any distinctions, exclutions or restrictions made on the basis of sex which has the effect or purpose of impairing or nullifying the recognition, enjoyment or exercice by women, inrespective of their marital status, on the basis of equality of men and women, of human rights and fundamental freedoms in political, economic, social, cultural, civil or any other field." 22

Berdasarkan ketentuan ini dilarang adanya suatu pembedaan atau pembatasanpembatasan yang didasarkan pada perbedaan jenis kelamin; antara laki-laki dan wanita memiliki kedudukan yang sama dalam hal hak asasi manusia dan dalam hal kebebasan yang bersifat fundamental dalam bidang politik, ekonomi, sosial, budaya, civil dan dalam bidang-bidang yang lainnya.

Ketentuan Konvensi yang berkaitan dengan kewajiban negara peserta, dalam hal melindungi dan menghormati hak asasi manusia (wanita pengungsi atau wanita yang sedang dalam pengungsian ) dituangkan dalam Pasal 6 sebägai berikut: "State Parties shall take all appropriate measures, including legislation, to suppress all forms of trafic in women and exploitation of prostitution of women." Dengan demikian negara-negara peserta harus mengambil langkah-langkah yang tepat; termasuk di bidang perundangundangan untuk memberantas dan memerangi semua bentuk perdagangan wanita dan eksploitasi terhadap pelacuran wanita. Karena pengungsi wanita (IDPs wanita) sangat rentan terhadap perdagangan wanita dan éksploitasi pelacuran. Oleh sebab itu negara-negara yang memberi toleransi atas keberlangsungan segala bentuk pelacuran yang eksploitatif dan praktik-praktik berbau perbudakan lainnya jelas merupakan pelanggaran terhadap ketentuan pasal ini:

\section{Konvensi tentang Hak Anak}

Konvensi tentang Hak-Hak Anak (Convention on the Rights of Child) diterima Majelis Umum PBB pada 20 Nopember 1989. Kemudian pada 2 September 1990 Konvensi ini mulai berlaku. Perhatian dan Perlindungan yang serius terhadap anak-anak secara internasional dilatarbelakangi oleh kenyataan bahwa anak-anak merupakan kelompok rawan akan tindakan kejahatan, eksploitasi dan pelecehan seksual. Konvensi ini memuat kewajiban negara-negara peserta untuk memberikan perlindungan terhadap anak: Oleh karena itu dimuat prinsip non-diskriminasi anak, di mana anak-anak menikmati hak-hak mereka, tanpa memandang ras, wama kulit, jenis kelamin, bahasa, agama, pendapat politik atau pendapat lainnya, kewarganegaraan, asal-usul kebangsaan atau sosial, kekayaan, kecacatan, kelahiran atau status lain dari orang tua. ${ }^{23}$

Dimuatnya prinsip "non-diskriminasi" ini, selain meletakkan standar-standar yang sama,

\footnotetext{
${ }^{22}$ Achmad Romsan, et. al., op. cit., hlm. 146.

${ }^{23}$ Pasal 2 ayat (1) Konvensi Hak-Hak Anak.
} 
juga memperhatikan realita adanya perbedaan budaya, sosial, ekonomi dan politik dari setiap negara, sehingga setiap negara dapat menentukan caranya masing-masing untuk menerapkan hak yang sama pada semua anak.

Dalam Konvensi ini terdapat empat prinsip umum yang harus ditaati dan dihormati, termasuk prinsip non diskriminasi. Keempat prinsip tersebut dimuat dalam Pasal 2, 3,6, dan 12 Konvensi Hak-Hak Anak. Pertama, prinsip "non-diskriminasi" dimuat dalam Pasal 2 yang intinya menyatakan:

"Negara-negara peserta harus memastikan bahwa semua anak dalam wilayahnya menikmati hak mereka. Tidak seorang anakpun akan menderita mengalami diskriminasi. Hal ini berlaku untuk semua anak, tanpa memandang ras, warna kulit, jenis kelamin, bahasa, agama, pendapat politik atau pendapat lainnya, kewarganegaraan dan, asal-usul kebangsaan, sosial, kekayaan, kecacatan, kelahiran atau status lain dari orang tua atau wali yang sah dari anak tersebut."

Hal penting dalam pasal ini ialah persamaan kesempatan antara semua anak. Anak-anak perempuan harus diberikan. kesempatan yang sama seperti halnya anak laki-laki. Pengungsi anak, anak-anak yang berasal dari negara lain, anak-anak kelompok penduduk asli atau kelompok minoritas harus memperoleh kesempatan yang sama untuk menikmati standar kehidupan yang memadai.

Kepentingan terbaik bagi anak dirumuskan dalam Pasal 3 yaitu jika penguasa suatu negara mengambil keputusan yang mempengaruhi anak-anak, pertimbangan pertama haruslah didasarkan pada kepentingan yang terbaik bagi anak. Prinsip ini berkenaan dengan keputusan pengadilan, pejabat administrasi, badan-badan legislatif dan juga lembagalembaga kesejahteraan sosial pemerintah maupun swasta.

Hak untuk hidup, kelangsungan hidup dan mengembangkan diri diatur dalam Pasal 6 . Pasal mengenai hak untuk hidup ini mencakup rumusan mengenai hak untuk bertahan dan hak untuk mengembangkan diri yang harus dijamin semaksimal mungkin. Istilah mengembangkan diri dalam konteks ini harus ditafsirkan dalam arti luas, dengan menambahkan tidak hanya dimaksudkan untuk jasmani, akan tetapi juga perkembangan mental, emosional kognitif, sosial dan budaya. ${ }^{24}$

Sebetulnya masih banyak lagi hak-hak anak yang diatur dalam Konvensi ini, akan tetapi dalam kesempatan ini hanya beberapa saja yang diuraikan, salah satunya ialah hakhak anak yang berkaitan dengan pengungsi anak. Anak dalam pengertian ini ialah anak yang ikut orang tuanya mengungsi atau anak yang lahir dari orang tua yang mengungsi. Ditentukan bahwa anak yang lahir di tempat pengungsian harus segera didaftarkan, dan sejak kelahirannya berhak untuk memperoleh sebuah nama, untuk memperoleh kewarganegaraan, dan sedapat mungkin untuk mengetahui orang tuanya dan dibesarkan oleh orang tuanya. Selain itu negara-negara peserta harus menjamın penerapan hak ini, sesuai dengan hukum nasional dan kewajiban mereka menunut instrumen internasional yang, relevan dalam bidang ini, khususnya apabila anak menjadi tanpa kewarganegaraan.

Konvensi-konvensi yang sudah diuraikan tersebut dapat dijadikan sebagai suatu

\footnotetext{
${ }^{24}$ Pasal 6 Konvensi Hak-Hak Anak.
} 
landasan hukum untuk memberikan suatu justifikasi apakah suatu negara wajib untuk menerima bantuan kemanusiaan dari organisasi internasional atau tidak akan sangat tergantung kepada kemauan dan kemampuan suatu negara dalam memberikan perlindungan dan bantuan kepada IDPs yang ada di wilayah negaranya.

\section{Tanggung Jawab Negara Terhadap IDPs}

IDPs merupakan persoalan klasik yang timbul dalam peradaban umat manusia sebagai akibat adanya rasa takut yang sangat mengancam keselamatan mereka. Ancaman itu dapat berupa bencana alam atau bencana akibat buatan manusia. Perpindahan penduduk dalam skala besar ini pada awalnya hanya merupakan persoalan domestik suatu negara, sehingga tidak banyak menarik perhatian masyarakat internasional. Masalah pengungsi domestik (IDPs) meluas menjadi persoalan negara-negara di kawasan tertentu saja dan terakhir dianggap merupakan masalah bersama umat manusia.

Bertilik tolak pada ketentuan internasional terhadap para pengungsi, dirasa perlu adanya bidang hukum baru dalam hukum internasional. Hukum pengungsi adalah sekumpulan peraturan yang diwujudkan dalam beberapa instrumen-instrumen internasional dan regional yang mengatur tentang standar baku perlakuan terhadap para pengungsi. Suatu negara yang bukan merupakan peserta atau tidak meratifikasi Konvensi Pengungsi Tahun 1951 dan Protokol tahun 1967 ataupun instrumen pengungsi yang lain, tidak berarti bahwa negara itu dapat melepaskan diri dari tanggung jawabnya sebagai anggota masyarakat internasional dalam menyelesaikan masalah pengungsi. ${ }^{25}$ Akan tetapi kedua instrumen tersebut belum mengatur tentang IDPs. Ketentuan tentang IDPs tertuang dalam bentuk Guiding Principles on Internal Displaced Persons.

Berkaitan dengan hak dan kewajiban negara sebagai anggota masyarakat internasional, maka penanganan masalah IDPs sebagaimana sudah diuraikan sebelumnya, akan dapat menimbulkan tanggung jawab negara. Dalam hukum internasional masalah tanggung jawab negara akan muncul, jika negara melakukan perbuatan melawan kukum, atau melanggar kewajiban internasional baik yang muncul dalam Konvensi Internasional maupun yang muncul dalam hukum kebiasaan internasional. Yang menjadi permasalahan ialah apakah kegagalan suatu negara untuk membantu dan melindungi hak-hak IDPs yang ada di wilayah negaranya merupakan pelanggaran hukum internasional dan memunculkan tangung jawab negara, "mengingat ketentuan-ketentuan yang mengatur tentang hakhak IDPs dan Kewajiban Negara hanya tertuang dalam suatu Guidance. Untuk menjawab permasalahan ini ada beberapa argumen yang dapat dimunculkan.

Pertama, untuk menjawab persoalan tersebut harus dilihat bagaimana ketentuan hukum internasional yang mengaturnya. Berdasarkan ketentuan yang termuat dalam Guiding Principles on Intemal Dispaced Persons disebutkan bahwa negara di mana terdapat IDPs memiliki kewajiban untuk memberikan bantuan dan perlindungan kepada IDPs, ${ }^{26}$ sehingga kalau suatu negara misalnya tidak mampu atạu tidak berkehendak untuk

${ }^{25}$ Achmad Romsan, et. al., op. cit., hlm. 87-89. 
membantu dan melindungi hak-hak IDPs seperti hak untuk hidup, untuk memperoleh fasilitas kesehatan, pendidikan, sanitasi dan lain-lain sebagaimana yang diatur dalam Guiding principles on Intemal Dispaced Persons tersebut, maka negara berkewajiban untuk menerima bantuan internasional tersebut. Kalau suatu negara tidak menerima bantuan internasional berarti negara yang bersangkutan akan tidak mampu untuk melaksanakan kewajiban untuk membantu dan melindungi hak-hak IDPs di negaranya. Kegagalan dalam melaksanakan kewajiban, sebagaimana yang sudah tertuang dalam Guiding principles on Internal Dispaced Persons akan menimbulkan pertanggung jawaban negara, jika sebagian ketentuanketentuan yang termuat di dalamnya merupakan suiatu jus Cogens. ${ }^{27}$

Kedua, ketidakmampuan atau kegagalan suatu negara untuk memberikan bantuan dan melindungi hak-hak IDPs jika dikaitkan dengan prinsip-prinsip umum suatu tindakan yang dapat menimbulkan tanggung jawab negara berdasarkan International Law Commission's Draft Article 1 dan 2 sebagai berikut:

1. Every intentionally wrongful act of a State entails the international responsibility of that State;

2. There is an internationally wrongful act of a State when conduct concisting of an act or omission: a. is attributable to the State under international law;

b. and constitute abreach of an intemational obligation of the state.28

Berdasarkan prinsip tersebut, pertama, negara bertanggungjawab atas suatu tindakan yang sengaja melanggar hukum internasional, kedua, negara melanggar kewajiban internasional, sehingga kalau pemberian bantuan dan perlindungan hak-hak pengungsi diasumsikan sebagai kewajiban internasional, maka pelanggaran dalam artian ketidakmampuan atau keengganan suatu negara untuk melindungi IDPs di negaranya merupakan pelanggaran kewajiban internasional dan memunculkan tanggung jawab negara.

Kewajban internasional ini dapat-muncul dalam Konvensi Internasional maupun dalam Hukum Kebiasaan Internasional, sèhingga kalau ketentuan-ketentuan yang termuat dalam IDPs sebagian isinya adalah kewajiban internasional yang sudah merupakan hukum kebiasaan dan bahkan merupakan jus cogens, seperti hak IDPs untuk hidup dan hak untuk tidak diperbudak, ${ }^{29}$ maka sudah jelas ini merupakan suatu kewajiban internasional yang harus dilakukan oleh suatu negara.

Kewajiban internasional yang tertuang dalam Perjanjian Internasional, misalnya tanggung jawab negara untuk melindungi hak asasi manusia sebagaimana yang tertuang

\footnotetext{
${ }^{28} \mathrm{http}: / / p d m$.medicine.wisc.edu/leus.pdf//nternally, "Displaced Persons," diakses 6 Juni 2005.

${ }^{27}$ I.A. Shearer, Starke's Intemational Law (London: Butterworths, 1994), hlm. 49-50, menyatakan /us Cogens include the fudamental rules conceming the safeguarding of peace... fundamental rules of a humanitarian nature (prohibition of genocide, slavery and racial discrimination, protection of essential rights of the human person in peace and war) the ruler prohibiting any infringements of the independence and sovereign equality of States, the rules which ensure to all the members of the international community the enjoyment of certain common resources (high seas, outer space, etc). Lihat juga Article 53 of the Vienna Convention on the Law of Treaties.

${ }^{28} \mathrm{lbid}$.

${ }^{29} \mathrm{lbid}$.
} 
dalam Declaration of Human Rights, Konvensi tentang pengungsi dan Konvensi Anti Penyiksaan, Konvensi tentang Hak-Hak Anak, dan Konvensi tentang Segala Bentuk Diskriminasi terhadap Wanita sebagaimana sudah diuraikan sebelumnya. Akan tetapi, kadang kendala yang dihadapi oleh para IDPs ialah IDPs tidak termasuk pengertian pengungsi.yang dilindungi oleh Konvensi Tahun 1951 maupun Protokol Tahun 1967. Ketentuan tentang IDPs ini hanya diatur dalam suatu Guiding Principles on Internal Displaced Persons yang tidak memiliki kekuatan hukum yang mengikat, karena memang bukan merupakan perjanjian internasional. Namun, karena prinsip-prinsip yang termuat dalam Guiding tersebut sangat manusiawi dan universal, beberapa ketentuannya merupakan jus cogen yang diadopsi dari berbagäi Konvensi Internasional dapat dikatakan bahwa prinsip-prinsip yang ada merupakan perwujudan dari kebiasaan internasional. ${ }^{30}$

\section{Kedaulatan Negara dan Akses Kemanusiaan}

Banyak teori dan argumen yang telah dikemukakan dalam rangka melegitimasi bantuan kemanusiaan tanpa persetujuan negara penerima. Richard Plender, berpendapat bahwa penolakan bantuan yang ditujukan kepada IDPs di suatu negara adalah pelanggarahtiak asasi manusia: ${ }^{31}$ Dengan lain perkataan bahwa ketidakmampuan negara unituk melindungi hak asasi manusia yang kemudian menimbulkan pelanggaran hak asasi manusia, maka akan merupakan legitimasi bagi ikut campurnya suatu negara untuk mengatasi masalah tersebut. Kegagalan suatu negara untuk melaksanakan kewajiban internasional dapat menyebabkan kehilangan kedaulatan negara. ${ }^{32}$

Masalah pengungsi dalam - negeri sebetulnya adalah masalah intern suatu negara, hal ini berkaitan dengan masalah kedaulatan dan prinsip non intervensi. Satu-satunya alasan untuk memasukkan IDPs dalam perlindungan hukum internasional ialah masalah kemanusiaan. Berkaitan dengan masalah perlindungan IDPs sebetulnya merupkan masalah kedaulatan negara untuk dapat melindungi dan menyediakan kebutuhan pokok IDPs dan menjamin perlindungan hak asasi manusia yang fundamental, seperti hak untuk hidup. Akan tetapi kalau negara tersebut tidak mampu untuk melaksanakan kewajibannya, maka negara tersebut berhak untuk meminta bantuan Organisasi internasional, misalnya memohon bantuan kepada UNHCR. Permasalahan muncul jika negara tidak mau meminta bantuan

${ }^{30}$ Mark E Villager, Cusiomary International Law (Boston : Martinus Nijhoff Publishers, 1985), hlm. 34-36.

${ }^{31}$ Geoff Gilbert, op. cit., hlm. 684.

${ }^{32}$ I. Brwonlie, Principle of International Law (Fith Edition, Clarendon University Press, 1998), hlm. 446 448. sebagaimana dikutif oleh Geoff Gilbert, op. cit., hlm. 684.

${ }^{33}$. Martin Dixon menyatakan: "Humanitarian Intervention "under doctrine of humanitarian intervention is an alleged general right to intervene with force for humanitarian purposes without the consent of the territorial sovereign, as where a government is systematically murdering whole sections of population. Certain condition have postulated for the lawful exercise of this right, for example, that the intervention must be authorized by. a competent organization and that the use of armed forced is legitimate only in cases of extreme deprivation of fundamental human rights, such as genocide."Lihat Martin Dixon, op. cit., hlm. 291. 
dan tidak mau dibantu, hal ini akan menimbulkan suatu justifikasi bagi masyarakat internasional untuk mengintervensi, misalnya karena adanya genocida terhadap IDPs di suatu negara. $^{33}$

Perlindungan terhadap IDPs merupakan perwujudan pertanggungjawaban negara. Dengan demikian berkaitan dengan hukum hak asasi manusia, negara memiliki kewajiban untuk melakukan suatu remedy atau tindakan hukum kalau terjadj pelanggaran hak asasi manusia di wilayah negara tersebut. Hal ini berkaitan dengan prinsip kedaulatan teritorial dalam hukum internasional publik. Berdasarkan hukum hak asasi manusia negara diwajibkan- untuk menggunakan local remedy terlebih dahulu, karena di wilayah teritorial tersebut terdapat buktibukti atas pelanggaran tersebut. ${ }^{34}$

Beberapa ahli hukum memberikan suatu argumen bahwa noma hak asasi manusia telah memberikan suatu perubahan besar dalam hukum internasional. Berhubungan dengan perlindungan hak asasi IDPs yang fundamental seperti; hak untuk hidup norma-norma hak asasi manusia telah membentuk suatu hukum internasional yang temporer. Lebih lanjut lagi, telah diinterpretasikan bahwa kedaulatan negara yang kontemporer telah menggantikan arti kedaulatan negara yang tradisional. ${ }^{35}$ Sehingga, campur tangan pihak asing dalam penegakan demokrasi di suatu negara bukanlah merupakan pelanggaran kedaulatan negara. Bahkan beberapa ahli berpendapat bahwa kedaulatan negara adalah suatu mitos. Terutama dalam kaitannya dengan penegakan hak asasi manusia, maka kedaulatan negara itu sudah. begitu kabur, karena masalah pelanggaran hak asasi manusia di suatu negara merupakan masalah negara lain juga.

Namun demikian intervensi yang dilakukan oleh suatu negara berdasarkan pernyataan sepihak bukanlah merupakan justifikasi untuk membenarkan intervensi suatu negara ke negara lain, sebagaimana dalam kasus Nikaragua. Sehingga tindakan yang dilakukan oleh suatu negara yang didasarkan pada ketidaksenangan terhadap ideologi tertentu tidak dapat dijadikan sebagai suatu justifikasi. ${ }^{36}$ Lagi pula, Majelis Umum PBB telah merekomendasikan adanya penghormatan terhadap kedaulatan negara, bantuan dalam bidang hak asasi manusia khususnya terhadap IDPs harus atas persetujuan dari negara penerima. Menurut Jennings, kedaulatan teritorial merupakan suatu faktor yang esensial dalam hukum internasional. Masalah yang muncul sekarang ini ialah adanya pemerintah suatu negara yang tidak mempunyai kedaulatan yang nyata. ${ }^{37}$ Dalam level yang pragmatis, ketika bantuan internasional diberikan kepada IDPs di suatu negara, banyak negara yang mensyaratkan adanya persetujuan dari negara penerima dan penghormatan kedaulatan. Bahkan bagi negara yang mendukung adanya bantuan kemanusiaan terhadap IDPs, sangat berhati-hati dalam menyikapi isu kedaulatan secara langsung.

${ }^{34}$ John O'Brien, International Law (London: Cavendish Publishing Limited, 2001), hlm. 476.

${ }^{35} \mathrm{~L}$. Henkin, "An Agenda for the Next Century: The Myth and Mantra of State Souvereignty," Virginia Journal of International Law, Vol. 35 (1994), hlm. 115 sebagaimana dikutip oleh Geoff Gilbert, op. cit., hlm. 682.

${ }^{36}$ Military and Paramilitary Activities In and Against Nicaragua (Nicaragua v United States of America), Merits, Judgment, 1986 ICJ Reports 14, paras. 262-263, sebagaimana dikutip oleh Geoff Gilbert, Ibid.

${ }^{37}$ Sir Robert Jennings, "Sovereignty and international Law," in G. Kreijer (ed). State, Souvereignty, and International Governance (Oxford Universitry Press, 2002), hlm. 27, 31 dan 35. 
Dalam kondisi yang spesifik, larangan intervensi harus mengesampingkan tentang campur tangan dalam hak asasi manusia ${ }^{36}$ Kalau suatu negara tidak dapat menunjukkan adanya suatu keseriusan tanggung jawab pemerintah untuk menangani masalah pengungsi dalam negeri (IDPs) dalam situasi konflik, komunitas internasional harus menjamin bahwa pihak korban telah memperoleh bantuan dan perlindungan untuk menyelamatkan hidupnya. Aksi seperti ini harus tidak diartikan sebagai suatu intervensi dalam keadaan konflik bersenjata. Lebih lanjut lagi, ICJ telah memutus perkara Nikaragua bahwa bantuan kemanusiaan tidak dapat diartikan sebagai suatu campur tangan yang melawan hukum, sepanjang sesuai dengan tujuan Palang Merah Internasional untuk mengurangi dan mencegah penderitaan manusia dan untuk melindungi kehidupan dan kesehatan manusia, serta jaminan terhadap hak asasi manusia dan dilaksanakan tanpa diskriminasi. ${ }^{39}$

\section{Kewajiban untuk Menerima Bantuan Kemanusiaan menurut Hukum Internasional}

Negara tidak hanya memiliki kewajiban untuk menghormati hak asasi manusia tetapi juga untuk menjamin dan melindungi hak asasi manusia. Hak untuk hidup mungkin merupakan suatu argumen yang paling kuat dalam hal menerima bantuan asing dalam perlindungan hak asasi manusia. Penyebab terjadinya internal IDPs, dapat disebabkan karena adanya konflik bersenjata, kekejaman internal atau karena adanya bencana alam.

Dalam hal terjadi konflik bersenjata internal ataupun bencana alam, jika pemerintah tidak mampu untuk memberikan perlindungan dan memberikan bantuan makanan atau dan bantuan kesehatan, berdasarkan Article 70 Protokol Tambahan I Konvensi Genewa 1949 mewajibkan kepada negara yang telah meratifikasi untuk menerima bantuan yang adil dan tidak diskriminatif dari masvarakat internasional. ${ }^{40}$ Tindakan seperti ini juga tidak diartikan sebagai tindakan tidak bersahabat. Karakteristik dari hukum humaniter ialah tindakan untuk memenuhi suatu kewajiban dalam rangka pemenuhan kebutuhan pihak korban. Tindakan tersebut harus bersifat adil, proporsional dan tidak diskriminatif. ${ }^{41}$ Suatu klausul dapat dicantumkan dalam perjanjian para pihak dalam rangka untuk melindunigi kedaulatan nasional negara penerima bantuan.

\section{Simpulan}

Negara sebagai salah satu subjek hukum internasional memiliki hak dan kewajiban yang harus diembannya, sehingga kalau suatu negara gagal melaksanakan kewajiban internasionalnya baik itu yang muncul dalam perjanjian internasional maupun dalam hukum kebiasaan

${ }^{38}$ R. Plender, "The Legal Basis of International Jurisdiction to Act with Regard to the Internally Displaced," 6 IJRL 345, 1994, sebagaimana dikutip oleh Geoff Gilbert, op. cit, hlm. 683.

${ }^{39}$ Nicaragua v. United states, supra note 36.

${ }^{40}$ Pasal 70 Protokol Tambahan I Konvensi Genewa 1949.

${ }^{41}$ Y. Sandoz, C. Swinarski \& B. Zimmermann (eds), Commentary on the Additional Protokols of 8 June 1997 to the Geneva Conventions of 12 August 1949, ICRC (Martinus Nijhotf Publishers, 1987), hlm. 817-818 sebagaimana dikutip oleh Geoff Gilbert, op. cit, hlm. 687. 
internasional akan mengkibatkan negara bertanggung jawab:

Berkaitan dengan kewajiban negara untuk membantu dan melindungi IDPs di wilayah negaranya akan memunculkan tanggung jawab negara jika negara gagal untuk membantu dan melindungi IDPs yang berada di wilayah negaranya. Dalam situasi seperti itu, munculnya bantuan yang berasal dari organisasi internasional untuk membantu suatu negara agar dapat melaksanakan kewajibannya merupakan suatu keharusan, dan penolakan bantuan yang berasal dari organisasi Intemasional merupakan pelanggaran kewajban intermasional. Namun demikian, pemberian bantuan yang berasal dari organisasi seharusnya atas persetujuan (consent) dari negara penerima bantuan, hal ini dalam rangka untuk mempertahankan dan menghormati prinsip non-intervensi dan prinsip kedaulatan negara.

\section{Daftar, Pustaka}

Achmad Romsan, et. al., Pengantar Pengungsi Internasional, Jakarta , UNHCR, 2003

Declaration of Human Rights

Dixon Martin, International Law, London, Blackstone Press Limited, Third Edition, 1996

E Villager Mark, Customary International Law, Boston, Martinus Nijhoff Publishers, 1985
Forbes Martin Susan, Pegangan untuk Penerapan Prinsip-Prinsip Panduan bagi Pengungsian Internal, UN-OCHA, Jakarta, 2002

Geoff Gilbert, ed, International Journal of Refugee Law, Human Rights Center University of Essex, Oxford Universirty Press, Vol. 15, No. 4, 2000

Guiding Principles on Internal Displacement. Huala Adolf, Aspek-Aspek Negara dalam Hukum Internasional, Rajawali Press, Jakarta, 1991

Jastram Kate dan Marilyn Achiron, Refugee

Protection: A Guide to International Refugee Law, UNHCR, 2001

Kreijer. G. (ed). State, Sovereignty, and International Governance, London, Oxford University Press, 2002 O'Brien John, International Law, London, Cavendish Publishing Limited, 2001

Shearer I. A., Starke's Intemational Law, London, Butterworths, 1994

http://pdm.medicine.wisc.edu/leus.pdf/nternally, "Displaced Persons," diakses 6 Juni 2005

Konvensi Internasional tentang Penghapusan segala Benrtuk Diskriminasi Rasial.

Konvensi Anti Penyiksaan. Konvensi Hak-Hak Anak.

Protokol Tambahan I Konvensi Genewa 1949. Republika, 5 Januari, 2005. 